\title{
PENGARUH INISIASI MENYUSU DINI (IMD) TERHADAP LAMA PELEPASAN PLASENTA PADA IBU BERSALIN KALA III
}

\author{
EFFECT OF EARLY BREASTFEEDING INITIATION (IMD) TO LENGTH OF PLACENTAL \\ RELEASE IN MATERNAL WOMB III \\ Yona Sari ${ }^{1}$, Sintha Sunarsih ${ }^{2}$ \\ ${ }^{12}$ Sekolah Tinggi Ilmu Kesehatan Abdurahman Palembang, Jl. Sukajaya No.7 Kol. H.Burlian KM. 5,5 \\ Palembang, Sumatera Selatan, Indonesia \\ email:Yonaasari@gmail.com ${ }^{1}$, Sinthasunarsih2904@gmail.com ${ }^{2}$
}

\begin{abstract}
ABSTRAK
Menurut UNICEF sebanyak 30.000 bayi yang biasanya meninggal pada bulan pertama kelahiran dapat diselamatkan dengan melakukan inisiasi menyusu dini. Inisiasi menyusu dini adalah proses membiarkan bayi menyusu sendiri segera setelah dilahirkan. Manfaat penting inisiasi menyusu dini adalah dapat mengurangi perdarahan ibu dan mempercepat pelepasan plasenta. Berdasarkan sumber Kemenkes RI (2013), kejadian perdarahan ibu masih sangat tinggi, 30,3\% ibu meninggal dunia akibat perdarahan. Sebagian besar kasus perdarahan pada masa nifas terjadi karena retensio plasenta 16-17\% kejadian retensio plasenta menyebabkan kasus perdarahan. Salah satu cara untuk mencegah terjadinya perdarahan akibat retensio plasenta yaitu dengan melakukan inisiasi menyusu dini. Penelitian ini bertujuan untuk mengetahui pengaruh inisiasi menyusu dini terhadap lama pelepasan plasenta pada ibu bersalin kala III. Penelitian ini menggunakan pendekatan True Experimental Design dengan rancangan Randomized Posttest Only Control Design. Dengan pengambilan sampel dilakukan secara accidental sampling. Hasil bivariat terdapatnya pengaruh inisiasi menyusu dini terhadap lama pelepasan plasenta ( $\rho$ value $=0,003$ ). Kesimpulan yang didapatkan dalam penelitian ini adalah ada pengaruh inisiasi menyusu dini terhadap lama pelepasan plasenta pada ibu bersalin kala III.
\end{abstract}

Kata kunci : Inisiasi Menyusu Dini, Lama Pelepasan Plasenta

\begin{abstract}
According to UNICEF as many as 30.000 babies who usually die in first month of birth can be saved by initiating early breastfeeding. Early breastfeeding initiation is the process of allowing the baby to breastfeed itself immediately after birth. An important benefit of early breastfeeding initiation is that it can reduce maternal bleeding and speed up placental release. Based on the Ministry of Health RI source (2013), the incidence of maternal bleeding is still very high, 30.3\% of mothers die due to bleeding. Most cases of bleeding during the puerperium occur because placental retention of $16-17 \%$ incidence of placental retention causes bleeding cases. One way to prevent bleeding from placental retention is to initiate early breastfeeding.This study aims to determine the effect of early breastfeeding initiation on the length of placental release in maternity mothers at III. This research uses True Experimental Design approach with Randomized Posttest Only Control Design.With the sampling taken by accidental sampling. Bivariate results showed the influence of early breastfeeding initiation on the length of placental release ( $\rho$ value $=0.003)$. The conclusions obtained in this study were that there was an effect of early breastfeeding initiation on the length of placental release in maternity mothers at III.
\end{abstract}

Keywords : Initiation of early breastfeeding, long release of placenta 


\section{PENDAHULUAN}

Inisiasi Menyusu Dini (IMD) adalah proses membiarkan bayi menyusu sendiri segera setelah dilahirkan dan disusui selama satu jam atau lebih, cara bayi melakukan Inisiasi Menyusu Dini (IMD) dinamakan the breast crawl atau merangkak mencari payudara. Prinsipnya Inisiasi Menyusu Dini merupakan kontak langsung antara kulit ibu dan kulit bayi, bayi ditengkurapkan didada atau diperut ibu selekas mungkin setelah seluruh badan dikeringkan kecuali pada telapak tangannya dan dibiarkan merangkak untuk mencari puting untuk segera menyusui. Kedua telapak tangan bayi dibiarkan tetap terkena air ketuban karena bau dan rasa cairan ketuban ini sama dengan bau yang dikeluarkan payudara ibu, dengan demikian ini menuntun bayi untuk menemukan puting ${ }^{1}$.

Prinsip Inisiasi Menyusu Dini (IMD) merupakan kontak langsung antara kulit ibu dan kulit bayi, bayi ditengkurapkan didada atau diperut ibu selekas mungkin setelah seluruh badan dikeringkan kecuali pada telapak tangannya dan dibiarkan merangkak untuk mencari puting untuk segera menyusu. Kedua telapak tangan bayi dibiarkan tetap terkena air ketuban karena bau dan rasa cairan ketuban ini sama dengan bau yang dikeluarkan payudara ibu, dengan demikian ini menuntut bayi untuk menemukan puting. Lemak yang menyamankan kulit bayi sebaiknya dibiarkan tetap menempel ${ }^{1}$.

Proses terbentuknya ASI adalah hormon prolaktin dari plasenta meningkat selama kehamilan tetapi biasanya ASI belum keluar karena masih dihambat oleh kadar estrogen yang tinggi. Pada hari kedua atau ketiga pasca persalinan, kadar estrogen dan progesteron turun drastis, sehingga pengaruh prolaktin lebih dominan dan pada saat inilah mulai terjadi sekresi ASI. Dengan menyusukan lebih dini terjadi perangsangan puting susu, terbentuklah prolaktin dari hipofisis, sehingga sekresi ASI semakin lancar. Dua reflek yang sangat penting dalam proses laktasi adalah reflek prolaktin dan reflek aliran (let down reflex). Bersama dengan pembentukan prolaktin oleh hipofisis anterior, rangsangan yang berasal dari isapan bayi ada yang dilanjutkan ke hipofisis posterior (neurohipofisis) yang kemudian dikeluarkan oksitosin. Melalui aliran darah, hormon ini diangkat menuju uterus yang dapat menimbulkan kontraksi pada uterus sehingga membnatu plasenta terlepas. Kontraksi dari sel akan memeras air susu yang telah diproduksi keluar dari alveoli dan masuk ke sistem duktus, selanjutnya mengalir melalui duktus laktiferus masuk ke mulut bayi. Apabila bayi disusui, maka gerakan menghisap yang berirama akan menghasilkan rangsangan saraf yang terdapat pada glandula pituitari posterior, sehingga keluar hormon oksitosin. Hal ini menyebabkan sel-sel mioepitel disekitar alveoli akan berkontraksi dan akan mengeluarkan ASI. Pengeluaran oksitosin selain dipengaruhi oleh isapan bayi, juga oleh reseptor yang terletak pada duktus. Apabila duktus melebar, maka secara reflek oksitosin dikeluarkan oleh hipofisis ${ }^{1}$.

Bakteri yang menguntungkan pada saat IMD adalah pada saat IMD bayi akan menjilati kulit ibunya, sehingga terjadi pemindahan bakteri baik dari ibu ke bayi yang dapat bermanfaat bagi pencernaan bayi, bayi baru lahir yang dilakukan Iniusiasi Menyusu Dini (IMD) akan mendapatkan asupan prebiotik secara teratur dari ASI. Dalam setriap ASI yang diminumnya, terdapat kandungan antibodi khusus yang dapat melindunginya dan mendorong bakteri baik dalam tubuhnya berkembang dengan optimal. Bakteri tersebut sangat bermanfaat untuk melindungi saluran pencernaan bayi yang memang belum sempurna diawal kehidupannya. Begitu banyak manfaat yang didapatkan dari Inisiasi Menyusu Dini (IMD), diantaranya dapat mengurangi 
stress pada bayi. Bayi akan lebih tenang, denyut jantung pun stabil ${ }^{1}$.

Terdapat beberapa manfaat penting Inisiasi Menyusu Dini yaitu mengurangi tingkat kematian bayi, menghangatkan bayi dengan cepat yaitu selama bayi merangkak mencari payudara dan ini akan menurunkan kematian karena kedinginan (hipotermi), pada bayi yang dilakukan Inisiasi Menyusu Dini (IMD) ini akan memberikan kekebalan tubuh yang baik, pada bayi yang terlambat diberi ASI atau bayi yang diinisiasi ASI setelah hari pertama kehidupan mengalami peningkatan resiko kematian neonatal meningkat hingga 2,4 kali. Penelitian ini juga mengungkapkan terjadi peningkatan presentase keselamatan bayi, yaitu jika bayi diberi ASI dalam satu hari pertama maka kehidupan bayi bisa diselamatkan sebanyak $16 \%$ dan apabila diinisiasi dalam satu jam pertama maka akan meningkat menjadi $22 \%$. Sementara menurut UNICEF sebanyak 30.000 bayi yang biasanya meninggal pada bulan pertama kelahirannya, dapat diselamatkan dengan melakukan Inisiasi Menyusu Dini (IMD) setelah satu jam pertama kelahiran. Selain itu manfaat penting IMD adalah dapat mengurangi perdarahan ibu. Dimana angka kejadian perdarahan ibu masih sangat tinggi, 30,3\% ibu meninggal dunia akibat perdarahan. Sebagian besar kasus perdarahan pada masa nifas terjadi karena retensio plasenta $16-17 \%$ kejadian retensio plasenta menyebabkan terjadinya kasus perdarahan $^{2}$.

Salah satu cara untuk mencegah terjadinya perdarahan akibat retensio plasenta yaitu dengan melakukan Inisiasi Menyusu Dini (IMD). Dimana pada saat bayi diletakkan di dada ibunya, ia berada tepat diatas rahim ibu. Hal itu membantu menekan plasenta dan mengecilkan rahim ibu. Dengan begitu, plasenta bisa lepas dengan cepat. Selain itu juga Inisiasi Menyusu Dini (IMD) dapat menjaga produktivitas ASI, mekanisme ini dimungkinkan karena isapan bayi penting dalam meningkatkan kadar hormon prolaktin, yaitu homon yang merangsang kelenjar susu untuk memproduksi ASI. Isapan itu akan meningkatkan produksi susu dua kali lipat ${ }^{1}$.

Sementara itu, bagi ibu sentuhan dan isapan pada payudara ibu mendorong terbentuknya oksitosin yang berdampak pada kontraksi uterus sehingga membantu lepasnya plasenta. Padasaat bayi menghisap puting susu ibu akan merangsang ujung-ujung saraf sensoris yang berfungsi sebagai reseptor mekanik. Rangsangan ini dilanjutkan ke hipotalamus melalui medula spinalis hipotalamus sehingga dapat memacu sekresi prolaktin. Isapan bayi memicu pelepasan ASI dari alveolus mammae melalui duktus sinus laktiferus. Isapan merangsang produksi oksitosin oleh kelenjar hipofisis anterior. Oksitosin memasuki darah dan menyebabkan kontraksi sel-sel khusus yang mengelilingi alveolus dan duktus laktiferus. Kontraksi ini mendorong ASI keluar dari alveolus melalui duktus laktiferus menuju sinus laktiferus dimana ia akan tersimpan. Pada saat bayi menghisap, ASI dalam sinus tertekan keluar ke mulut bayi. Bersama dengan pembentukan prolaktin oleh hipofisis anterior, rangsangan yang berasal dari isapan bayi ada yang dilanjutkan ke hipofisis posterior (neorohipofisis) yang kemudian dikeluarkan oksitosin. Melalui aliran darah, hormon ini diangkat menuju uterus yang dapat menimbulkan kontraksi pada uterus sehingga terjadi involusi dari organ tersebut dan terjadi pelepasan plasenta. Kontraksi dari sel akan memeras air susu yang telah diproduksi keluar dari alveoli dan masuk ke sistem duktus, selanjutnya mengalir melalui duktus laktiferus masuk ke mulut bayi. Selain itu, gerakan kaki bayi pada saat merangkak di perut ibu akan membantu merangsang uterus sehingga otot miometrium berkontraksi. Kontraksi uterus ini akan membantu pengeluaran plasenta dan mengurangi terjadinya perdarahan. Penyusutan rongga uterus akan menyebabkan berkurangnya ukuran tempat 
implantasi plasenta. Karena tempat implantasi menjadi sangat kecil, plasenta terlepas. Kontraksi menyebabkan bagian yang longgar dan lemah dari plasenta pada dinding rahim terlepas, mula-mula sebagian dan kemudian seluruhnya dan tinggal bebas dalam kavum uteri. Namun, terkadang ada sebagian kecil plasenta yang masih melekat pada dinding rahim. Proses pelepasan plasenta ini biasanya setahap demi setahap dan pengumpulan darah dibelakang plasenta akan membantu pelepasan plasenta. Bila pelepasan plasenta sudah komplit, maka kontraksi rahim mendorong plasenta yang sudah lepas ke segmen bawah rahim, lalu ke vagina dan dilahirkan ${ }^{3}$.

Berdasarkan penelitian terdahulu yang telah dilakukan pada bulan Desember 2011 diketahui bahwa di RSUD Koja Jakarta dan RSUD Kota Bekasi telah diadakan program Inisiasi Menyusu Dini (IMD). Berdasarkan data yang didapatkan di RSUD Koja Jakarta dan RSUD Kota Bekasi pada bulan Mei sampai dengan pertengahan bulan juli 2011 terdapat 60 responden yang terbagi menjadi 30 orang kelompok intervensi dan 30 orang kelompok kontrol. RSUD Koja dipilih sebagai tempat penelitian dengan kelompok intervensi, sedangkan RSUD Kota Bekasi dipilih sebagai tempat penelitian dengan kelompok kontrol. Dari hasil pelaksanaan Inisiasi Menyusu Dini tersebut didapatkan data bahwa 25 responden $(83,3 \%)$ ibu yang melaksanakan Inisiasi Menyusu Dini mengalami pelepasan plasenta lebih cepat sedangkan 5 responden $(16,7 \%)$ mengalami pengeluaran plasenta yang lambat. Ibu yang tidak melakukan Inisiasi Menyusu Dini (IMD) dari 30 responden terdapat 25 responden $(83,3 \%)$ mengalami pelepasan plasenta lebih lambat dibandingkan dengan ibu yang melakukan Inisiasi Menyusu Dini (IMD) 5 responden $(16,7 \%)$ mengalami pelepasan plasenta lebih cepat. Memperlihatkan ratarata lamanya persalinan kala III pada kelompok yang tidak dilakukan IMD adalah 10,80 menit sedangkan untuk lamanya persalinan kala III pada kelompok yang dilakukan IMD adalah 5,57 menit ${ }^{4}$.

Penelitian ini juga didukung oleh penelitian yang dilakukan di Ghana yang diterbitkan di jurnal Pediatrics dengan sampel 10.947 bayi yang lahir antara juli 2003 hingga juni 2004, diperoleh hasil cukup mencengangkan yaitu sebesar $16 \%$ kematian neonatal (bayi berusia dibawah 28 hari) dapat dicegah jika bayi diberi kesempatan menyusui setelah 24 jam petama dan sebanyak $22 \%$ kematian neonatal dapat dicegah jika bayi baru lahir diberi kesempatan mulai menyusu sendiri dalam satu jam pertama setelah lahir(Inisiasi Menyusu Dini). Hal tersebut menarik perhatian peneliti tentang pengaruh Inisiasi Menyusu Dini (IMD) terhadap lama pelepasan plasenta pada ibu bersalin kala III persalinan di BPM Choirul Mala Palembang Tahun 2018.

Berdasarkan permasalahan tersebut di atas maka perlu dilakukan penelitian mengenai "Pengaruh Inisiasi Menyusu Dini (IMD) terhadap Lama Pelepasan Plasenta pada Ibu Bersalin Kala III DiBPM Choirul Mala Palembang Tahun 2018".

\section{METODE PENELITIAN}

Penelitian ini menggunakan True Experimental Design yang bersifat Randomized Posttest Only Control Design, rancangan jenis ini yaitu kelompok intervensi dan kontrol dipilih secara acak, kemudian kelompok intervensi diberi perlakuan (treatment), sedangkan yang lainnya tidak diberi perlakuan dan kemudian langsung diamati dan diukur ${ }^{5}$.

Sampel dalam penelitian ini adalah seluruh ibu bersalin di BPM Choirul Mala Palembang dengan menggunakan teknik Accidental Sampling.

Analisa Univariat dilakukan terhadap tiap variabel dari hasil penelitian. Pada umumnya dalam analisa ini hanya 
menghasilkan distribusi dan presentase dari tiap variabel ${ }^{6}$.

Analisa ini dilakukan untuk melihat distribusi frekuensi, baik variabel independen (Pengaruh Inisiasi Menyusu Dini) dan variabel dependen (Lama Pelepasan Plasenta pada Kala III).

Analisa Bivariat akan dilakukan terhadap dua variabel yang berhubungan atau berkorelasi, yaitu variabel independen dan variabel dependen menggunakan $U j i$ Statistik ${ }^{5}$.

Analisa ini digunakan untuk membandingkan proses lamanya pelepasan plasenta pada ibu bersalin yang dilakukan Inisiasi Menyusu Dini (IMD) dan tidak dilakukan Inisiasi Menyusu Dini (IMD).

\section{HASIL PENELITIAN}

univariat

$$
\text { frekuensi Inisiasi Menyusu Dini }
$$

(IMD)

Tabel 1. Distribusi frekuensi ibu bersalin yang melakukan Inisiasi Menyusu Dini (IMD) di BPM Choirul Mala Palembang Tahun 2018

\begin{tabular}{ccc}
\hline Inisiasi Menyusu & \multicolumn{2}{c}{ Jumlah } \\
\cline { 2 - 3 } Dini & Frekuensi & Persentase \\
\hline Ya & 8 & $50 \%$ \\
Tidak & 8 & $50 \%$ \\
\hline Jumlah & 16 & $100 \%$ \\
\hline
\end{tabular}

Dari Tabel 1 di atas dapat dilihat bahwa dari 16 responden yang melakukan inisiasi menyusu dini sebanyak 8 responden dengan persentase $50 \%$ dan yang tidak melakukan inisiasi menyusu dini sebanyak 8 responden dengan persentase $50 \%$.

Lama Pelepasan Plasenta

Tabel 2. Distribusi frekuensi lamanya pelepasan plasenta pada ibu bersalin di BPM Choirul Mala PalembangTahun 2018

\begin{tabular}{lccccc}
\hline \multicolumn{1}{c}{ Lama Pelepasan } & \multicolumn{2}{c}{ Jumlah } & \multirow{2}{*}{ Pean } & \multirow{2}{*}{ Min } & \multirow{2}{*}{ Max } \\
\cline { 2 - 3 } \multicolumn{1}{c}{ Plasenta } & 8 & 50 & & & \\
\hline Cepat jika $<5$ menit & 7 & 43,75 & 4,19 & \multirow{2}{*}{1} & 20 \\
Normal jika 5-15 menit & 1 & 6,25 & & & \\
Lambat jika $>15$ menit & 16 & $100 \%$ & 4,19 & 1 & 20 \\
\hline Total & &
\end{tabular}

Berdasarkan Tabel 2 di atas dapat diketahui bahwa rata-rata lama pelepasan plasenta ibu bersalin yaitu 4,19 menit dengan waktu minimum lama pelepasan plasenta yaitu 1 menit dan waktu maksimum 20 menit.

Analisa Bivariat, pengaruh frekuensi Inisiasi Menyusu Dini (IMD) terhadap lama pelepasan plasenta pada ibu bersalin kala III di BPM Choirul Mala Palembang Tahun 
Tabel 3. Pengaruh frekuensi Inisiasi Menyusu Dini (IMD) terhadap lama pelepasan plasenta pada ibu bersalinkala III di BPM Choirul MalaPalembang Tahun 2018

\begin{tabular}{|c|c|c|c|c|c|c|c|}
\hline \multirow{3}{*}{$\begin{array}{c}\text { Lama Pelepasan } \\
\text { Plasenta }\end{array}$} & \multicolumn{4}{|c|}{$\begin{array}{c}\text { Inisiasi Menyusu } \\
\text { Dini }\end{array}$} & \multirow{2}{*}{\multicolumn{2}{|c|}{ Jumlah }} & \multirow{3}{*}{$\begin{array}{c}\mathbf{P} \\
\text { Value }\end{array}$} \\
\hline & \multicolumn{2}{|c|}{ Ya } & \multicolumn{2}{|c|}{ Tidak } & & & \\
\hline & $\mathbf{n}$ & $\%$ & $\mathbf{n}$ & $\%$ & $\mathbf{N}$ & $\%$ & \\
\hline Cepat $<5$ menit & 8 & $50 \%$ & 0 & $0 \%$ & 8 & $0 \%$ & \\
\hline Normal 5-15 menit & $\mathrm{O}$ & $0 \%$ & 7 & $43,8 \%$ & 7 & $43,8 \%$ & 0.003 \\
\hline Lambat $>15$ menit & $\mathrm{O}$ & $0 \%$ & 1 & $6,25 \%$ & 1 & $6,25 \%$ & \\
\hline Jumlah & 8 & & 8 & & 16 & & \\
\hline
\end{tabular}

Berdasarkan hasil uji statistik Chi-Square didapatkan nilai $\rho$ value $=0,003$ lebih kecil dari $\alpha=0,05(\rho$ value $\leq \alpha)$. Dengan demikian Ha diterima dan Ho ditolak, hal ini menunjukkan bahwa ada hubungan yang bermakna antara frekuensi inisiasi menyusu dini terhadap lama pelepasan plasenta.

\section{PEMBAHASAN}

Analisa univariat, frekuensi Inisiasi Menyusu Dini (IMD). Dalam penelitian ini terdapat 16 responden yang melakukan inisiasi menyusu dini sebanyak 8 responden dengan persentase $50 \%$ dan yang tidak melakukan inisiasi menyusu dini sebanyak 8 responden dengan persentase $50 \%$.

Inisiasi Menyusu Dini (early initiation) atau permulaan menyusu dini adalah proses membiarkan bayi menyusu sendiri segera setelah dilahirkan dan disusui satu jam atau lebih. Inisiasi Menyusu Dini (IMD) adalah proses menyusu bukan menyusui yang merupakan gambaran bahwa inisiasi menyusu dini bukan program ibu menyusui bayi tetapi bayi yang harus aktif sendiri menemukan puting susu ibu ${ }^{1}$.

Prinsipnya Inisiasi Menyusu Dini (IMD) merupakan kontak langsung antara kulit ibu dan kulit bayi, bayi ditengkurapkan didada atau diperut ibu selekas mungkin setelah seluruh badan dikeringkan kecuali pada telapak tangannya dan dibiarkan merangkak untuk mencari puting untuk segera menyusui. Kedua telapak tangan bayi dibiarkan tetap terkena air ketuban karena bau dan rasa cairan ketuban ini sama dengan bau yang dikeluarkan payudara ibu, dengan demikian ini menuntun bayi untuk menemukan puting. Lemak yang menyamankan kulit bayi sebaiknya dibiarkan tetap menempel ${ }^{1}$.

Manfaat inisiasi menyusu dini adalah untuk membantu mempercepat pelepasan plasenta, karena pada saat proses inisiasi menyusu dini sentuhan dan isapan pada payudara ibu mendorong terbentuknya oksitosin yang berdampak pada kontraksi uterus sehingga membantu lepasnya plasenta ${ }^{1}$.

Dari 16 responden yang dilakukan penelitian terdapat 8 responden yang tidak melakukan Inisiasi Menyusu Dini (IMD), hal ini dilatarbelakangi karena ketidaksediaan responden untuk melakukan inisiasi menyusu dini, kejadian perdarahan, terjadinya asfiksia pada bayi baru lahir dan adanya kejadian plasenta akreta sehingga tidak dimungkinkan untuk melakukan inisiasi menyusu dini.

Lama pelepasan plasenta, berdasarkan hasil penelitian pada Tabel 2 diketahui bahwa rata-rata lama pelepasan plasenta ibu bersalin yaitu 4,19 menitdengan waktu minimum lama pelepasan plasenta yaitu 1 menit dan waktu maksimum 20 menit. Hal tersebut menunjukkan bahwa sebagian responden mengalami lama pelepasan plasenta dalam kategori cepat.

Menurut teori yang ada menunjukkan bahwa plasenta lahir spontan kategori cepat $<5$ menit, normal 5-15 menit dan lambat > 15 menit setelah bayi lahir. Cepatnya pelepasan plasenta dikarenakan beberapa faktor salah satunya adalah karena dilakukannya Inisiasi 
Menyusu Dini (IMD), karena pada saat melakukan inisiasi menyusu dini terjadi hentakan kaki bayi yang menekan perut ibu sehingga memunculkan hormon oksitosin dan membantu membuat rahim berkontraksi dan terjadilah pelepasan plasenta ${ }^{7}$.

Pada penelitian ini pelepasan plasenta berlangsung secara cepat, cepatnya pelepasan plasenta ini disebabkan oleh gerakan kaki bayi pada saat merangkak di perut ibu, karena pada saat bayi merangkak diatas perut ibu kaki bayi menekan perut ibu sehingga memunculkan hormon oksitosin dan membantu membuat rahim berkontraksi dan terjadilah pelepasan plasenta. Selain itu, faktor lain yang menyebabkan percepatan pelepasan plasenta adalah kondisi kandung kemih yang tidak penuh sehingga membuat kontraksi uterus semakin adekuat dan terjadi pelepasan plasenta

Masih adanya ibu bersalin yang mengalami pelepasan plasenta lambat dikarenakan oleh kontraksi rahim yang tidak adekuat yang bisa disebabkan karena tidak dilakukannya inisiasi menyusu dini, kandung kemih yang penuh dan paritas.

Analisa bivariat, dari hasil perhitungan uji statistik Chi-Square didapatkan nilai $\rho$ value $=0,003$, hal ini berarti nilai $\rho$ value $<0,05$ maka ada pengaruh yang signifikan antara inisiasi menyusu dini terhadap lama pelepasan plasenta.

Menurut Maryunani (2013), dengan melakukan inisiasi menyusu dini segera setelah bayi lahir ada banyak sekali manfaatnya salah satunya adalah membantu mempercepat pelepasan plasenta, dimana pada saat bayi diletakkan di dada ibunya, ia berada tepat diatas rahim ibu. Hal itu membantu menekan plasenta dan mengecilkan rahim ibu. Dengan begitu, plasenta bisa lepas dengan cepat. Selain itu, bagi ibu sentuhan dan isapan pada payudara ibu mendorong terbentuknya oksitosin yang berdampak pada kontraksi uterus sehingga membantu lepasnya plasenta. Padasaat bayi menghisap puting susu ibu akan merangsang ujung-ujung saraf sensoris yang berfungsi sebagai reseptor mekanik. Rangsangan ini dilanjutkan ke hipotalamus melalui medula spinalis hipotalamus sehingga dapat memacu sekresi prolaktin. Isapan bayi memicu pelepasan ASI dari alveolus mammae melalui duktus sinus laktiferus. Isapan merangsang produksi oksitosin oleh kelenjar hipofisis anterior. Oksitosin memasuki darah dan menyebabkan kontraksi sel-sel khusus yang mengelilingi alveolus dan duktus laktiferus. Kontraksi ini mendorong ASI keluar dari alveolus melalui duktus laktiferus menuju sinus laktiferus dimana ia akan tersimpan. Pada saat bayi menghisap, ASI dalam sinus tertekan keluar ke mulut bayi. Bersama dengan pembentukan prolaktin oleh hipofisis anterior, rangsangan yang berasal dari isapan bayi ada yang dilanjutkan ke hipofisis posterior (neorohipofisis) yang kemudian dikeluarkan oksitosin. Melalui aliran darah, hormon ini diangkat menuju uterus yang dapat menimbulkan kontraksi pada uterus sehingga terjadi involusi dari organ tersebut dan terjadi pelepasan plasenta. Kontraksi dari sel akan memeras air susu yang telah diproduksi keluar dari alveoli dan masuk ke sistem duktus, selanjutnya mengalir melalui duktus laktiferus masuk ke mulut bayi. Selain itu, gerakan kaki bayi pada saat merangkak di perut ibu akan membantu merangsang uterus sehingga otot miometrium berkontraksi. Kontraksi uterus ini akan membantu pengeluaran plasenta dan mengurangi terjadinya perdarahan ${ }^{1}$.

Selain sentuhan dan isapan pada payudara ibu, kontak dini pada saat IMD juga memberikan pengaruh pada pelepasan plasenta. Karena pada saat kontak dini sewaktu IMD terjadi peningkatan kedekatan dan rasa kasih sayang antara ibu dan bayi. Ketika proses IMD, bayi akan mengalami kontak kulit secara langsung antara bayi dan ibu (skin to skin contact). Kontak kulit secara langsung antara ibu dan bayi (skin to skin contact) pada jam pertama setelah lahir itulah yang dapat mempererat ikatan batin antara ibu dengan bayi. Selama proses IMD, ibu akan merasa nyaman (rileks) saat melihat 
bayinya yang baru lahir menyusu kepadanya sehingga tubuh ibu akan memproduksi hormon oksitosin dan prolaktin yang dapat berperan sebagai letdown reflex. Dengan meningkatnya hormon oksitosin tersebut maka dapat membuat otot miometrium berkontraksi dan mempercepat pelepasan plasenta $^{8}$.

Dalam penelitian ini dapat disimpulkan bahwa jika ibu bersalin melakukan inisiasi menyusu dini atau memberikan ASI segera setelah lahir ada banyak sekali manfaat yang diperoleh baik pada bayi maupun pada ibunya. Sentuhan dengan kulit ibu memberikan kehangatan dan ketenangan. Bayi juga akan memperoleh antibodi yang berarti bayi memperoleh imunisasinya yang pertama. Sementara itu, sentuhan dan hisapan pada payudara ibu serta gerakan kaki bayi pada perut ibu mendorong terbentuknya oksitosin yang berdampak pada kontraksi pada uterus sehingga membantu lepasnya plasenta.

\section{KESIMPULAN DAN SARAN}

Diketahui ibu bersalin yang melakukan Inisiasi Menyusu Dini (IMD) sebanyak 8 responden $(50 \%)$

Diketahui lamanya pelepasan plasenta pada ibu bersalin adalah 8 responden $(50 \%)$ cepat $<5$ menit, sebanyak 7 responden $(43,75 \%)$ normal 5-15 menit dan hanya 1 responden $(6,25 \%)$ lambat

Ada pengaruh yang signifikan antara Inisiasi Menyusu Dini (IMD) terhadap lama pelepasan plasenta pada kala III dengan nilai $\rho$ value 0,003

Bagi BPM Choirul Mala Palembang, Diharapkan dapat memberikan informasi mengenai pengaruh inisiasi menyusu dini terhadap lama pelepasan plasenta kepada ibu yang sedang hamil dan memberikan dorongan untuk melakukan IMD.

Bagi Institusi Pendidikan, diharapkan dapat ikut berperan aktif dalam memberikan promosi kesehatan bagi ibu hamil. Hal tersebut dapat dilakukan dengan cara memberikan edukasi tentang pentingnya Inisiasi Menyusu Dini (IMD) dengan cara memberikan materi tentang inisiasi menyusu dini dan praktik tekhnik menyusui yang benar. Setelah pemberian materi dilakukan sesi tanya jawab perihal Inisiasi Menyusu Dini (IMD).Untuk menghilangkan rasa jenuh ibu hamil maka dilakukan permainan.

Bagi Peneliti Selanjutnya, diharapkan pada penelitian selanjutnya mempunyai sampel yang lebih banyak.

\section{DAFTAR PUSTAKA}

1. Maryunani Anik, 2013. Buku Inisiasi Menyusui Dini dan ASI Eksklusif. Jakarta: TIM

2. Kemenkes RI, 2013. http://Direktorat Kesehatan RI.com/2013/Penyebab Kematian Ibu. Diakses 02 pada tanggal 02 Mei

3. Depkes

RI,2013.http://KESMASpublichealth.co m/2013/12/Inisiasi Menyusui Dini. Diakses pada tanggal 07 Maret

4. Setyawati Prihatin, 2013. Pengaruh Inisiasi Menyusui Dini (IMD) Terhadap Lama Pengeluaran Plasenta. GrahamedikaJakarta: Salemba Medika

5. Notoatmodjo Soekidjo, 2012. Buku Metodologi Penelitian Kesehatan. Jakarta: Rineka Cipta

6. Wibowo, 2014. Buku Metodologi Penelitian Kebidanan. Jakarta: Salemba Medika

7. Daiyah Isrowiyatun, Susanti Ari, Laila Ani, dkk, 2012. Buku Ajar Asuhan Kebidanan Persalinan. Jakarta: EGC

8. Dewi Lia Nanny Vivian, Sunarsih Tri, 2011. Buku Asuhan Kebidanan Pada Ibu Nifas. Jakarta: Salemba Medika 